University of South Florida

DIGITAL COMMONS

Digital Commons @ University of

@ UNIVERSITY OF SOUTH FLORIDA

South Florida

USF Accountability Reports

USF Archives

$1-1-2019$

\title{
2019 Accountability Plan System
}

USF

Follow this and additional works at: https://digitalcommons.usf.edu/usf_accountability_reports

\section{Scholar Commons Citation}

USF, "2019 Accountability Plan System" (2019). USF Accountability Reports. 75.

https://digitalcommons.usf.edu/usf_accountability_reports/75

This Article is brought to you for free and open access by the USF Archives at Digital Commons @ University of South Florida. It has been accepted for inclusion in USF Accountability Reports by an authorized administrator of Digital Commons @ University of South Florida. For more information, please contact digitalcommons@usf.edu. 


\section{9 \\ Accountability Plan}

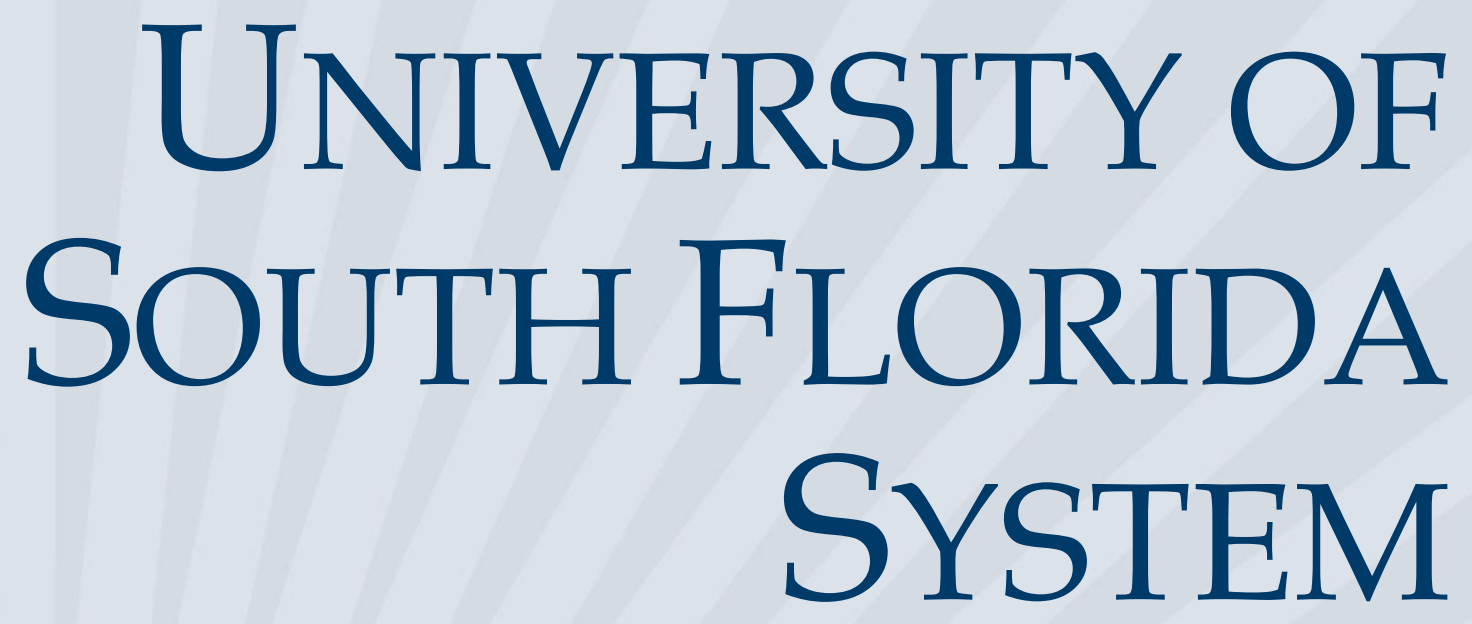

FINAL FOR BOG SUBMISSION

REVISED BY BOARD OF GOVERNORS, JUNE 2019

STATE UNIVERSITY SYSTEM of FLORIDA Board of Governors 


\section{INTRODUCTION}

This is a new report that combines the previous Annual Accountability Report and University Work Plans into a single document more closely aligned with the Board of Governors' 2025 System Strategic Plan.

This revised document will enhance the System's commitment to accountability and strategic planning by enabling comparisons between past goals and actual data to better assess performance, helping to foster greater coordination between institutional administrators, University Boards of Trustees, and the Board of Governors.

Once an Accountability Plan is approved by each institution's respective Boards of Trustees, the Board of Governors will review and consider the plan for approval, excluding those sections of the Plan that require additional regulatory or procedural approval pursuant to law or Board regulations. 


\section{TABLE OF CONTENTS}

\section{STRATEGY}

a. Mission \& Vision Statements, p. 3

b. Statement of Strategy, p. 4

c. Strengths, Opportunities \& Challenges, p. 5

d. Key Initiatives \& Investments, p. 6-8

e. Graduation Rate Improvement Plan, p. 9

f. Key Achievements for Last Year, p. 10-11

2. PERFORMANCE BASED FUNDING METRICS, p. 12-13

3. PREEMINENT RESEARCH UNIVERSITY METRICS, p. 14-16

\section{KEY PERFORMANCE INDICATORS}

a. Teaching \& Learning, p. 17-18

b. Scholarship, Research and Innovation, p. 19-21

c. Institution Specific Goals, p. 21

5. ENROLLMENT PLANNING, p. 22-23

6. ACADEMIC PROGRAM COORDINATION, p. 24 


\section{MISSION STATEMENT}

The University of South Florida System, which includes USF Tampa, USF St. Petersburg, and USF Sarasota-Manatee, catalyzes and coordinates initiatives at and among its interdependent institutions to prepare students for successful 21 st century careers; advances research, scholarship, and creative endeavors to improve the quality of life; and engages its communities for mutual benefit.

\section{VISION STATEMENT}

The University of South Florida System will empower and connect its institutions into a distinctive system that is nationally and globally recognized for innovation in teaching and research; for attracting outstanding and diverse scholars, staff, and students; and for transforming the communities in which we operate as well as those where our graduates apply their skills. 


\section{STATEMENT OF STRATEGY \\ Given your mission, strengths and available resources, provide a brief description of your market and your strategy for addressing and leading it.}

The primary focus of the University of South Florida (USF) is to provide access to qualified students to a Preeminent education that promotes student success, timely graduation, with minimal debt while preparing students to compete in today's competitive global workplace. USF is equally committed to research with impact that generates new knowledge and economic growth while collaborating regionally, nationally, and globally. Comprised of USF Tampa, USF St. Petersburg, and USF SarasotaManatee, the University of South Florida is guided by the State University of Florida Board of Governors' (BOG) Strategic Plan and driven by a commitment to accountability.

In the Spring of 2018, the Florida Excellence in Higher Education Act of 2018 was established into law, requiring the USF campuses to consolidate under a single accreditation. Consolidation offers additional opportunities to leverage the unique identity of each campus while continuing to provide a world-class education as one geographically-distributed university. As we continue to work on this significant effort, USF is committed to remaining focused on strengthening Preeminence, optimizing Performance-Based Funding outcomes, and advancing our collective strategic priorities while continuing to serve the best interest of our students, the region, and the state of Florida.

USF St. Petersburg offers a high-quality education with small class sizes and a close-knit learning environment. Located on the waterfront in the heart of bustling downtown St. Petersburg, the campus offers opportunities for innovation and collaboration with businesses and cultural institutions, providing students the ability to explore their passions, be creative and get hands-on experience outside the classroom.

USF Sarasota-Manatee provides a personalized learning community that prepares successful leaders and responsible citizens. USF Sarasota-Manatee is part of Sarasota's Cultural Corridor and offers a smaller, personalized learning setting while on a scenic campus.

USF Tampa serves as the major metropolitan Preeminent research university and is classified as both a Doctoral University with "Highest Research Activity" and as a "Community Engaged" institution by the Carnegie Classification of Institutions of Higher Education. Offering a diverse range of academic programs, USF Tampa provides ample opportunities for research in every department. As $1^{\text {st }}$ in Florida and 5th in the nation among all public universities and 12th world-wide for granted U.S. patents, USF Tampa is deeply committed to innovation, research, and economic development. USF Tampa continues on its mission to establish a profile consistent with membership in the Association of American Universities (AAU).

USF is in the midst of unprecedented growth to meet growing workforce needs in healthcare through strategic partnerships, including the new Morsani College of Medicine a critical part of the redevelopment of the Channelside District. 


\section{STRENGTHS, OPPORTUNITIES AND CHALLENGES (within 3 years)}

What are your major capabilities, opportunities and challenges for improvement?

The combined force of USF's three distinctive campuses and the collective ability to serve the evolving needs of its students, local communities, and the state of Florida remain its greatest strength. The process to achieve singular accreditation no later than July 1, 2020, presents a significant undertaking as well as opportunities to maximize our collective strengths. With the consolidation process well underway, several critical milestones have been met with many more to come as we work toward the submission of the SACSCOC "Substantive Change Prospectus" by March 15, 2020, and other strategic considerations.

As a leader and national model for student success, USF will continue to deliver programs in areas of strategic emphasis, graduate research and doctoral opportunities across all three campuses that respond to the unique local needs and market demands for each of its communities. At the heart of our student success initiatives is the synergistic dedication of USF's world-class faculty. Each working to address society's most pervasive problems and create a growing economy for the region, the state, and the nation ensure the collective success of our 50,000 students.

Last summer, USF Tampa was designated by the Board of Governors as a "Preeminent State Research University" achieving 11 of the 12 metrics prescribed by law. Currently, only USF Tampa meets the benchmarks set in law to achieve this designation. Achieving Preeminence is a significant milestone in USF's mission to deliver competitive undergraduate, graduate, and professional programs, to generate knowledge, foster intellectual development, and ensure student success in a global environment. Consolidation offers an opportunity to strengthen USF's stature by allowing all students and graduates to attend and graduate from a Preeminent university.

USF recently launched a new academic logo and brand effort designed to enhance the University's national reputation and promote USF as a top academic destination for the best and brightest students and faculty, as well as an economic driver for the region. The brand will focus on a broad array of key academic initiatives while engaging audiences nationally and globally. 


\section{KEY INITIATIVES \& INVESTMENTS (within 3 years)}

Describe your top three key initiatives for the next three years that will drive improvement in Academic Quality, Operational Efficiency, and Return on Investment.

\section{Continue to provide a Preeminent education while promoting student success and preparing graduates to compete in today's competitive global workplace:}

USF is committed to providing an environment where students graduate on time, with minimal debt, and achieve success through the following key initiatives:

- Persistence, retention, and student success teams across campuses are developing new initiatives aimed at providing greater support to students to enhance the academic progress rate as well as the four- and six-year graduation rates.

- Archivum software is now being utilized across all three campuses to provide faculty the ability to refer students to academic advising at the first indication of academic difficulty.

- Providing a high-quality, affordable education through the work of the Textbook Affordability Program and the newly formed USF Student Debt Committee; which has developed financial literacy modules, enhanced financial aid orientation, and increased scholarship opportunities.

- Launched Reimaging Summer Pilot Program which includes the expansion of intersession and summer terms to provide greater access and streamline a pathway to four-year graduation.

- To promote timely graduation, USF is committed to providing greater scholarship opportunities including Finish in Four, Stay AFloat fund, and Stay the Course.

- The wellbeing and mental health of our students remains a top priority across all campuses. To address these important issues, USF has created MWell4Success program which includes an array of support services from therapy to time-management, anxiety-reducing skills, and stress coping strategies.

- Understanding the value of on-campus living in enhancing student learning and encouraging faculty and peer group interactions, USFSP will be breaking ground and opening a 375 studentoccupancy residence hall in the spring of 2019. USFSM has recently completed a housing feasibility study and discussions on the development of new living-learning communities are underway. USF Tampa fully realized its housing expansion with the completion of The Village in the fall of 2018. 


\section{Enhance research and academic program quality to prepares students for high-skilled, high need jobs:}

In keeping with USF's mission to create knowledge and discover solutions to global problems while preparing students to compete in the workforce, USF is recruiting and retaining Preeminent, researchproductive faculty and students. To meet evolving workforce needs, students are exposed to multilevel research opportunities and a career-readiness models that focuses on professional experiences while connecting degree programs to careers. Many initiatives are underway including:

- The development of a new STEM Inquiry lab housed at USFSP designed to help educators and students utilize new technologies while promoting STEM learning, particularly among populations that are currently underrepresented in STEM fields, including young women and students of color.

- USFSP was asked to develop and offer an online program in Accountancy on behalf of all USF campuses. The program launched in September and exceeded enrollment expectations by more than 65 percent.

- Expanded College of Nursing programs. USFSM and USFSP communities will be offering an accelerated second-degree nursing program. Undergraduates possessing a bachelor's degree in this program will complete a nursing degree in two semesters, and help meet the growing demand for nurses in their respective regions.

- Newly created department of Medical Engineering, a joint program between the Morsani College of Medicine and College of Engineering, is opening a new wet lab space for students and faculty to conduct research on tissue engineering, regenerative medicine and biomedicine.

- Morsani College of Medicine and Heart Institute will open late 2019 and place an emphasis on unmet medical needs related to cardiovascular disease. Housed on Water Street in Tampa, it will become a crucial part the world's first ever WELL-certified district, Enhance and establish state of the art telecommunication connections between campuses for teaching, seminars, and collaborative meetings, which will augment the learning environment and contribute to the interconnectedness of the newly consolidated USF System.

- Enhance research via Nexus, by establishing external partnerships that will provide intellectual and infrastructural stimuli to advance ongoing graduate and undergraduate work at USF, as well as increase scholarship opportunities and interdisciplinary research.

- The establishment of a Phi Beta Kappa society chapter, the oldest and most prestigious national honor organization in the United States. Phi Beta Kappa will provide high achieving faculty with access to with unique and sought-after merit-based scholarships, as well as a network of highly distinguished professionals. 


\section{Increased partnerships and maximize efficiencies:}

In its inaugural year, the USF Office of Corporate Partnerships has contributed to an increase in industry-related grants and contracts for research, identified new and enhanced philanthropic partnership opportunities, and helped streamline the collaboration experience at USF for both faculty and corporate partners. Most recently, the Office worked with USF faculty in a range of disciplines to host a corporate forum on innovations in Aging \& Technology. The forum showcased USF faculty research and gave visiting corporate partners from around the world an opportunity to learn about USF's expertise and identify areas of alignment for potential sponsored research projects.

The Office continues to serve as the front door to the University by fielding inquiries from companies and guiding them through the USF campuses to address their interests in areas such as hiring, research, and academic program engagement as efficiently and effectively as possible. The Office has established a network of key contacts across the University who are engaged in corporate partnership activity within their respective departments, and these contacts guide the company through the next steps of its engagement experience at USF.

USF Sarasota-Manatee has established a Community Engagement team to organize and enhance corporate partnership activity for its programs that leverages both the local character and unique offerings of USFSM, as well as system-wide USF resources to grow strategic partnerships for the campus. For example, USFSM has established a Risk Management \& Insurance (RMI) program that is unique to the USFSM campus and responds to a critical need identified by the corporate community. Additionally, USFSM is working with the USF Colleges of Nursing and Engineering, as well as the USF Office of Corporate Training \& Professional Education, to best link students at USFSM with a range of opportunities available.

USF St. Petersburg also brings its distinctive character and local advantages to the corporate engagement conversation at USF through unique programs that address an industry need, such as its programs in Graphic Arts and Ethical Leadership, as well as partnerships with USF resources such as the Office of Corporate Training \& Professional Education. This combination of local strengths and regional resources provides both students and corporate partners across the region with an engagement experience that is both comprehensive and tailored to their unique interests and goals.

Consolidation presents the opportunity to develop further initiatives and partnerships to promote access and support our diverse student body. The FUSE program, a partnership between all three USF campuses and eight Florida Colleges, provides a seamless pathway to receive an Associate degree from a partnering state college and a Bachelor's degree from USF. Students in the program are co-advised and tracked as FUSE students and are guaranteed admission to USF upon successful completion of the Associate degree. 


\section{Graduation Rate Improvement Plan}

This narrative subcomponent is in response to the "Florida Excellence in Higher Education Act of 2018" that revised section 1001.706(5), Florida Statutes, to require each university board of trustees to submit a comprehensive proposal to improve undergraduate four-year graduation rates to the Board of Governors for implementation beginning in the fall of 2018 academic semester.

\section{Provide a brief update on the academic, financial, financial aid and curricular actions that your institution has implemented to encourage graduation in four years. [1 page max]}

The Graduation Rate Improvement plan implemented by the USF System in 2018 built on and enhanced comprehensive, system-wide initiatives then underway, including, but not limited to 1) predictive analytics, 2) case management, 3) course scheduling, and 4) the Finish in Four program. USF has made substantial progress in each one of these areas.

1). Predictive Analytics: The Civitas Learning analytics platform has been extended to users at USFSP and USFSM. Lists of at-risk students are distributed around the campuses every week. Further, our institutional research office worked with Civitas to modify the platform to predict a students' likelihood of persistence to the following fall semester (rather than semester to semester). In addition, the in-house predictive models built on pre-enrollment data and surveys (known as the First Year Retention model), were also developed for USFSP and USFSM.

2). Case Management: The cross-functional Persistence Committees have been strengthened at all three campuses by standardizing the practices utilized by the professional staff. In addition, Information Technology enhanced the case management communications platform, Archivum Insights, to allow for appointment scheduling and text messaging. Support personnel across the three campuses are developing and operating under a common "playbook" to share best practices and train additional personnel.

3) Course Scheduling. In the fall of 2019 College schedulers across the USF System began to receive training in the Ad Astra platform to assist in developing course schedules that optimize seats and facilitate timely degree completion. A nationally recognized firm, Ad Astra promotes student success by empowering course schedulers with more accurate projections of student course demand. USF also launched a task force to develop a summer course schedule that will include a twelve-week session that will allow more STEM students to enroll in summer coursework.

4) Finish in Four. To encourage students to graduate in four years, the university awarded $\$ 353,000$ in financial incentives to FTIC students in the 2014 cohorts who were just short of 120 credit hours. The awards contributed to an increase in the USF Tampa four-year graduation rate from 55\% in 2016 to $60 \%$ in 2017 and $61 \%$ in 2018 . In 2017, USF developed the Green to Gold Grant program to offer additional financial incentives to Florida resident summer/fall FTIC admits who have a zero expected family contribution. This grant, in combination with the Federal Pell Grant, covers tuition, fees and books. To date, we have paid 532 students $\$ 1,177,943$ for 2018-19. We did not exclude Bright Futures recipients from eligibility. 


\section{Key Achievements for 2017-18}

\section{STUDENT ACHIEVEMENTS}

1. USF was home to 63 national scholarship and fellowship student awardees including Boren, Fulbright, Gilman, and Goldwater during the 2017- 18 academic year.

2. First year USFSP student Rachel Cruz worked with Dr. Jolan Walter, division head of allergy and immunology at USF, on a clinical case study to explore additional treatment options for heart transplant patients who struggle with post-surgery complications. She was the only undergraduate presenting research at the 2018 meeting of the Clinical Immunology Society in Canada.

3. Joining an elite group nationally, USFSM student Anthony Alibro is accepted into the National Institutes of Health's prestigious post-baccalaureate program to assist a research project examining connections in the brain and the impacts of neurotransmitters like dopamine, glutamate and serotonin.

\section{FACULTY ACHIEVEMENTS}

1. For the fourth year in a row, USF Tampa ranked 4th worldwide for organizations with the most Fellows of the American Association for the Advancement of Science (AAAS) named in 2017. As of 2018, USF has a total of 60 AAAS Fellows among its faculty.

2. The Chronicle of Higher Education ranked USF \#5 as the nation's top producer of Fulbright Scholars, with eight faculty scholars for the 2017-2018 academic year.

3. USFSP's Yasin Elshorbany, Assistant Chemistry Professor, was awarded part of an $\$ 800,000$ grant from the National Science Foundation for collecting and analyzing aerosol to help answer questions regarding air quality and global climate change.

4. Dr. Giti Javidi, Dr. Ehsan Sheybani and Dr. Lila Rajabion received a Microsoft-supported grant to create workshops to encourage high school girls to explore computer science careers.

\section{PROGRAM ACHIEVEMENTS}

1. The Morsani College of Medicine brought in its most selective incoming medical student cohort to date, with an average MCAT score of 515, placing it among the top of all medical schools in the country.

2. USFSM was part of a joint $\$ 100,000$ grant to establish cybersecurity programs and launched a pre-nursing program and college a college-readiness program for high school students.

3. The Bank of America Charitable Foundation awarded USF St. Petersburg a $\$ 500,000$ grant to support the Merrill Lynch Wealth Management Center, a state-of the-art venue for students to analyze stocks, assess investment opportunities and apply skills learned in class to manage wealth. The grant also bolsters financial literacy initiatives, such as a finance academy for high school students, programs on budget management for college students and social security and retirement workshops for the greater St. Petersburg community. 


\section{INSTITUTIONAL ACHIEVEMENTS}

1. In June 2018, the Florida Board of Governors designated USF Tampa a "Preeminent State Research University" one of only three in the State of Florida.

2. USF reached $\$ 568$ million in total research expenditures in fiscal year $2016 / 17$ according to the National Science Foundation HERD Survey.

3. USF ranks 25th among public universities for research spending - a metric used to chart the level of research activity at American institutions - according to the National Science Foundation

4. USF was ranked \#6 in the U.S. and \#36 worldwide among public universities established in the "Golden Age" (1945-1966) by Times Higher Education (2018).

5. USF St. Petersburg adopted its first-ever Diversity and Inclusion Action Plan, which clearly defines, publicizes and implements the University's commitment to diversity and inclusion. It is intended to create a welcoming environment for all regardless of race, gender identity, age, disability, faith, nationality, ethnicity, socio-economic background, job role, culture viewpoints or familial status.

6. USFSM opens the "FUSE Bull Room" at State College of Florida to enhance transfer-student admissions and appoints a full-time onsite advisor to assist SCF students in transitioning to USFSM. 


\section{PERFORMANCE BASED FUNDING METRICS}

1. Percent of Bachelor's Graduates Enrolled or Employed $(\$ 25,000+)$

\begin{tabular}{cccccccccc} 
& $2012-13$ & $2013-14$ & $2014-15$ & $2015-16$ & $2016-17$ & $2017-18$ & $2018-19$ & $2019-20$ & $2020-21$ \\
\hline ACTUAL & 65.3 & 67.2 & 69.6 & 70.0 & 70.4 &. &. &. &. \\
APPROVED GOALS &. &. & 66.8 & 70.5 & 70.5 & 71.5 & 72.5 & 73.0 &. \\
PROPOSED GOALS &. &. &. &. &. & 71.4 & 72.5 & 73.1 & 74.0
\end{tabular}

2. Median Wages of Bachelor's Graduates Employed Full-time

\begin{tabular}{cccccccccc} 
& $2012-13$ & $2013-14$ & $2014-15$ & $2015-16$ & $2016-17$ & $2017-18$ & $2018-19$ & $2019-20$ & $2020-21$ \\
\hline ACTUAL & 35,200 & 36,700 & 38,000 & 37,300 & 38,012 &. &. &. &. \\
APPROVED GOALS &. &. & 36,300 & 38,600 & 39,100 & 39,600 & 40,100 & 40,700 &. \\
PROPOSED GOALS &. &. &. &. &. & 38,768 & 40,375 & 40,980 & 41,544
\end{tabular}

3. Average Cost to the Student [Net Tuition \& Fees per 120 Credit Hours for Resident Undergraduates]

\begin{tabular}{cccccccccc} 
& $2013-14$ & $2014-15$ & $2015-16$ & $2016-17$ & $2017-18$ & $2018-19$ & $2019-20$ & $2020-21$ & $2021-22$ \\
\hline ACTUAL & 14,490 & 13,540 & 13,280 & $12,960 *$ & 7,130 &. &. &. &. \\
APPROVED GOALS &. &. &. & 13,000 & 12,900 & 12,800 & 12,700 & 12,700 &. \\
PROPOSED GOALS &. &. &. &. &. & 7,110 & 7,110 & 7,110 & 7,110
\end{tabular}

Note*: Previous year data updated to reflect the change in methodology made by Board ODA staff to improve accuracy.

\section{FTIC Four-Year Graduation Rate [Full-time only]}

\begin{tabular}{cccccccccc} 
& $2010-14$ & $2011-15$ & $2012-16$ & $2013-17$ & $2014-18$ & $2015-19$ & $2016-20$ & $2017-21$ & $2018-22$ \\
\hline ACTUAL & 43.2 & 48.8 & $52.0^{*}$ & $57.4^{*}$ & 58.6 &. &. &. &. \\
APPROVED GOALS &. &. & 50.4 & 53.0 & 57.6 & 59.2 & 61.8 & 64.1 &. \\
PROPOSED GOALS &. &. &. &. &. & $59.2^{\dagger}$ & $61.8^{\dagger}$ & $64.1^{\dagger}$ &.
\end{tabular}

Note*: Previous year data updated to reflect the change in methodology made by Board ODA staff to improve accuracy.

Notet: The proposed goals were revised by the Board of Governors at their June 2019 meeting to match the previously approved goals from the 2018 Accountability Plan. These revisions to the proposed goals do not need to be re-approved by the university board.

\section{Academic Progress Rate [Second Year Retention Rate with At Least a 2.0 GPA]}

\begin{tabular}{cccccccccc} 
& $2013-14$ & $2014-15$ & $2015-16$ & $2016-17$ & $2017-18$ & $2018-19$ & $2019-20$ & $2020-21$ & $2021-22$ \\
\hline ACTUAL & 85.3 & 85.1 & 86.1 & $86.2^{*}$ & 86.4 &. &. &. &. \\
APPROVED GOALS &. &. & 85.6 & 87.5 & 87.4 & 89.0 & 89.6 & 90.5 &. \\
PROPOSED GOALS &. &. &. &. &. & 89.0 & 90.3 & 90.8 & 91.4
\end{tabular}

Note*: Previous year data updated to reflect the change in methodology made by Board ODA staff to improve accuracy.

Note: Metrics are defined in appendix. For more information about the PBF model visit: http://www.flbog.edu/about/budget/performance funding.php. 


\section{PERFORMANCE BASED FUNDING METRICS (CONTINUED)}

6. Percentage of Bachelor's Degrees Awarded within Programs of Strategic Emphasis

\begin{tabular}{cccccccccc} 
& $2013-14$ & $2014-15$ & $2015-16$ & $2016-17$ & $2017-18$ & $2018-19$ & $2019-20$ & $2020-21$ & $2021-22$ \\
\hline ACTUAL & 51.0 & 54.6 & 59.0 & 61.4 & 61.5 &. &. &. &. \\
APPROVED GOALS &. &. & 54.8 & 59.2 & 61.7 & 62.3 & 62.9 & 63.5 &. \\
PROPOSED GOALS &. &. &. &. &. & 62.2 & 63.5 & 64.5 & 65.4
\end{tabular}

7. University Access Rate [Percent of Undergraduates with a Pell grant]

$\begin{array}{lllllllll}\text { FALL } 2013 & \text { FALL } 2014 & \text { FALL } 2015 & \text { FALL } 2016 & \text { FALL } 2017 & \text { FALL 2018 } & \text { FALL } 2019 & \text { FALL 2020 } & \text { FALL } 2021\end{array}$

\begin{tabular}{cccccccccc}
\hline ACTUAL & 42.1 & 43.0 & 41.2 & 40.0 & 41.7 &. &. &. &. \\
APPROVED GOALS &. &. & 40 & 41 & 40.5 & 40.5 & 40.5 & 40.6 &. \\
PROPOSED GOALS &. &. &. &. &. & 42.2 & 42.2 & 42.2 & 42.2
\end{tabular}

8. Percentage of Graduate Degrees Awarded within Programs of Strategic Emphasis

\begin{tabular}{cccccccccc} 
& $2013-14$ & $2014-15$ & $2015-16$ & $2016-17$ & $2017-18$ & $2018-19$ & $2019-20$ & $2020-21$ & $2021-22$ \\
\hline ACTUAL & 69.0 & 72.7 & 74.6 & 74.8 & 73.3 &. &. &. &. \\
APPROVED GOALS &. &. & 74.0 & 74.1 & 75.2 & 75.3 & 75.8 & 75.8 &. \\
PROPOSED GOALS &. &. &. &. &. & 73.6 & 73.8 & 73.8 & 73.8
\end{tabular}

9. BOG Choice: Percent of Baccalaureate Degrees Awarded Without Excess Hours

\begin{tabular}{cccccccccc} 
& $2013-14$ & $2014-15$ & $2015-16$ & $2016-17$ & $2017-18$ & $2018-19$ & $2019-20$ & $2020-21$ & $2021-22$ \\
\hline ACTUAL & 63.9 & 65.8 & 75.6 & 78.3 & 80.7 &. &. &. &. \\
APPROVED GOALS &. &. & 68.1 & 77.5 & 79.0 & 79.6 & 80.2 & 80.3 &. \\
PROPOSED GOALS &. &. &. &. &. & 81.6 & 81.7 & 82.6 & 83.1
\end{tabular}

\subsection{Current BOT Choice: Number of Postdoctoral Appointees}

FALL 2013 FALL 2014 FALL 2015 FALL $2016 \quad$ FALL $2017 \quad$ FALL 2018 FALL $2019 \quad$ FALL $2020 \quad$ FALL 2021

\begin{tabular}{ccccccccccc}
\hline ACtUAL & 321 & 300 & 282 & 272 & $281^{*}$ &. &. &. &. \\
APPROVED GOALS &. &. &. & 272 & 267 & 267 & 267 & 267 &. \\
PROPOSED GOALS &. &. &. &. &. & 315 & 315 & 316 & 317
\end{tabular}

Note*: Revised since reported to NSF.

\begin{tabular}{|c|c|c|c|c|c|c|c|c|c|}
\hline & 2008-14 & 2009-15 & $2010-16$ & 2011-17 & 2012-18 & 2013-19 & 2014-20 & 2015-21 & 2016-22 \\
\hline ACTUAL & 66.0 & 67.7 & 66.4 & 68.8 & 71.2 & . & . & . & . \\
\hline APPROVED GOALS & . & . & 66.7 & 70.0 & 69.0 & 71.0 & 74.0 & 75.0 & . \\
\hline PROPOSED GOALS & & & . & . & . & 71.3 & 72.1 & 72.1 & 73.3 \\
\hline
\end{tabular}

Note: This is a transition year for the BOT Choice metric (\#10), so we are reporting data for both the current and future metrics. Metrics are defined in appendix. For more information about the PBF model visit: http://www.flbog.edu/about/budget/performance funding.php 


\section{PREEMINENT RESEARCH UNIVERSITY FUNDING METRICS (USF-TAMPA ONLY)}

\section{1a. Average GPA}

\begin{tabular}{|c|c|c|c|c|c|c|c|c|c|}
\hline & Fall 2014 & Fall 2015 & Fall 2016 & Fall 2017 & Fall 2018 & Fall 2019 & Fall 2020 & Fall 2021 & Fall 2022 \\
\hline ACTUAL & 4.0 & 4.1 & 4.1 & 4.1 & 4.1 & . & . & . & . \\
\hline APPROVED GOALS & . & . & 4.0 & 4.1 & 4.1 & 4.1 & 4.1 & 4.1 & . \\
\hline PROPOSED GOALS & . & . & . & . & . & 4.1 & 4.1 & 4.1 & 4.1 \\
\hline \multicolumn{10}{|c|}{ 1b. Average SAT Score* } \\
\hline & Fall 2014 & Fall 2015 & Fall 2016 & Fall 2017 & Fall 2018 & Fall 2019 & Fall 2020 & Fall 2021 & Fall 2022 \\
\hline ACTUAL & $1197^{*}$ & $1223^{*}$ & $1226^{*}$ & $1280^{*}$ & 1296 & . & r & . & . \\
\hline APPROVED GOALS & . & . & 1220 & 1280 & 1282 & 1285 & 1290 & 1290 & . \\
\hline PROPOSED GOALS & . & . & & . & . & 1296 & 1300 & 1302 & 1305 \\
\hline \multicolumn{10}{|c|}{ Note*: Historical scores and approved goals were based upon a different SAT scale standard. } \\
\hline \multicolumn{10}{|c|}{ 2. Public University National Ranking [Top50 rankings based on BOG's official list of publications] } \\
\hline & 2015 & 2016 & 2017 & 2018 & 2019 & 2020 & 2021 & 2022 & 2023 \\
\hline ACTUAL & 3 & 4 & 4 & 4 & 4 & . & . & . & . \\
\hline APPROVED GOALS & . & . & 3 & 5 & 5 & 5 & 5 & 5 & . \\
\hline PROPOSED GOALS & . & . & . & . & . & 5 & 5 & 5 & 5 \\
\hline
\end{tabular}

\section{Freshman Retention Rate [Full-time students as reported to IPEDS]}

\begin{tabular}{ccccccccccc} 
& $2013-14$ & $2014-15$ & $2015-16$ & $2016-17$ & $\mathbf{2 0 1 7 - 1 8}$ & $\mathbf{2 0 1 8 - 1 9}$ & $\mathbf{2 0 1 9 - 2 0}$ & $\mathbf{2 0 2 0 - 2 1}$ & $\mathbf{2 0 2 1 - 2 2}$ \\
\hline ACTUAL & 89 & 88 & 90 & 90 & 91 &. &. &. & &. \\
APPROVED GOALS &. &. & 90 & 91 & 91 & 91 & 92 & 92 &. \\
PROPOSED GOALS &. &. &. &. &. & 91 & 92 & 93 & 93
\end{tabular}

Note: Metrics are defined in appendix. For more information about the PBF model visit: http://www.flbog.edu/about/budget/performance_funding.php 


\section{PREEMINENT RESEARCH UNIVERSITY FUNDING METRICS (CONT.) (USF TAMPA ONLY)}

4. Four-year Graduation Rate [Full-time students only]

\begin{tabular}{cccccccccc} 
& $2010-14$ & $2011-15$ & $2012-16$ & $2013-17$ & $2014-18$ & $2015-19$ & $2016-20$ & $2017-21$ & $2018-22$ \\
\hline ACTUAL & 44 & 51 & 55 & 60 & 61 &. &. &. &. \\
APPROVED GOALS &. &. & 50 & 56 & 60 & 62 & 64 & 64 &. \\
PROPOSED GOALS &. &. &. &. &. & 62 & 64 & 65 & 67.5
\end{tabular}

5. National Academy Memberships

\begin{tabular}{cccccccccc} 
& 2015 & 2016 & 2017 & 2018 & 2019 & $\mathbf{2 0 2 0}$ & $\mathbf{2 0 2 1}$ & $\mathbf{2 0 2 2}$ & 2023 \\
\hline ACTUAL & 9 & 8 & 11 & 13 & 14 &. &. &. &. \\
APPROVED GOALS &. &. & 9 & 10 & 13 & 13 & 13 & 13 &. \\
PROPOSED GOALS &. &. &. &. &. & 14 & 15 & 16 & 17
\end{tabular}

6. Science \& Engineering Research Expenditures (\$M)

\begin{tabular}{cccccccccc} 
& $2013-14$ & $2014-15$ & $2015-16$ & $2016-17$ & $2017-18$ & $2018-19$ & $2019-20$ & $2020-21$ & $2021-22$ \\
\hline ACTUAL & 438 & 420 & 448 & 502 & 525 &. &. &. &. \\
APPROVED GOALS &. &. & 421 & 427 & 503 & 504 & 505 & 506 &. \\
PROPOSED GOALS &. &. &. &. &. & 530 & 545 & 560 & 575
\end{tabular}

7. Non-Medical Science \& Engineering Research Expenditures (\$M)

\begin{tabular}{cccccccccc} 
& $2013-14$ & $2014-15$ & $2015-16$ & $2016-17$ & $2017-18$ & $2018-19$ & $2019-20$ & $2020-21$ & $2021-22$ \\
\hline ACTUAL & 239 & 229 & 229 & 288 & 296 &. &. &. &. \\
APPROVED GOALS &. &. & 230 & 233 & 289 & 290 & 291 & 292 &. \\
PROPOSED GOALS &. &. &. &. &. & 296 & 300 & 305 & 310
\end{tabular}

8. Number of Broad Disciplines Ranked in Top 100 for Research Expenditures

\begin{tabular}{ccccccccccc} 
& $2012-13$ & $2013-14$ & $2014-15$ & $2015-16$ & $2016-17$ & $2017-18$ & $2018-19$ & $2019-20$ & $2020-21$ \\
\hline ACTUAL & 7 of 8 & 7 of 8 & 7 of 8 & 7 of 8 & 7 of 8 &. &. &. & \\
APPROVED GOALS &. &. & 7 of 8 & 8 of 8 & 8 of 8 & 8 of 8 & 8 of 8 & 8 of 8 &. \\
PROPOSED GOALS &. &. &. &. &. & 8 of 8 & 8 of 8 & 8 of 8 & 8 of 8
\end{tabular}

Note: Metrics are defined in appendix. For more information about the PBF model visit: http://www.flbog.edu/about/budget/performance funding.php 


\section{PREEMINENT RESEARCH UNIVERSITY FUNDING METRICS (CONT.) (USF TAMPA ONLY)}

9. Utility Patents Awarded [over three calendar years]

\begin{tabular}{cccccccccc} 
& $2012-14$ & $2013-15$ & $2014-16$ & $2015-17$ & $2016-18$ & $2017-19$ & $2018-20$ & $2019-21$ & $2020-22$ \\
\hline ACTUAL & 291 & 297 & 314 & 324 & 335 &. &. &. &. \\
APPROVED GOALS &. &. & 291 & 273 & 325 & 325 & 325 & 325 & $\cdot$ \\
PROPOSED GOALS &. &. &. &. &. & 323 & 306 & 309 & 312
\end{tabular}

10. Doctoral Degrees Awarded Annually

\begin{tabular}{cccccccccc} 
& $2013-14$ & $2014-15$ & $2015-16$ & $\mathbf{2 0 1 6 - 1 7}$ & $\mathbf{2 0 1 7 - 1 8}$ & $\mathbf{2 0 1 8 - 1 9}$ & $\mathbf{2 0 1 9 - 2 0}$ & $\mathbf{2 0 2 0 - 2 1}$ & $\mathbf{2 0 2 1 - 2 2}$ \\
\hline ACTUAL & 546 & 601 & 704 & 721 & 702 &. &. &. &. \\
APPROVED GOALS &. &. & 645 & 650 & 725 & 730 & 735 & 740 &. \\
PROPOSED GOALS &. &. &. &. &. & 717 & 720 & 725 & 725
\end{tabular}

\section{Number of Post-Doctoral Appointees*}

\begin{tabular}{ccc|c|cccccc} 
& Fall 2013 & Fall 2014 & $\begin{array}{c}\text { Fall 2015 } \\
\text { OFFICIAL }\end{array}$ & Fall 2016 & Fall 2017 & Fall 2018 & Fall 2019 & Fall 2020 & Fall 2020 \\
\hline ACTUAL & 321 & 300 & 277 & 267 & $276^{*}$ &. &. &. &. \\
APPROVED GOALS & 321 & 300 & 277 & 267 & 260 & 260 &. &. &. \\
PROPOSED GOALS &. &. &. &. &. & 308 & 308 & 308 & 308
\end{tabular}

Note*: There is a time lag for the count of Post-Doctoral Appointees because statute requires that this data is as reported by the Center for Measuring University Performance in their annual Top American Research Universities (TARU) report. Revised since reported to NSF. Modified non-substantive edit post-submission.

\section{Endowment Size (\$Millions)}

\begin{tabular}{cccccccccc} 
& $2013-14$ & $2014-15$ & $2015-16$ & $2016-17$ & $\mathbf{2 0 1 7 - 1 8}$ & $\mathbf{2 0 1 8 - 1 9}$ & $\mathbf{2 0 1 9 - 2 0}$ & $\mathbf{2 0 2 0 - 2 1}$ & $\mathbf{2 0 2 1 - 2 2}$ \\
\hline ACTUAL & 417 & 417 & 395 & 442 & 480 &. &. &. &. \\
APPROVED GOALS &. &. & 395 & 412 & 450 & 465 & 485 & 500 &. \\
PROPOSED GOALS &. &. &. &. &. & 466 & 486 & 505 & 525
\end{tabular}

Note: Metrics are defined in appendix. For more information about the PBF model visit: http://www.flbog.edu/about/budget/performance funding.php 


\section{KEY PERFORMANCE INDICATORS}

Teaching \& Learning Metrics (from the 2025 System Strategic Plan that are not included in the PBF section)

Public University National Ranking [Number of Top50 Rankings based on BOG's official list of publications]

\begin{tabular}{cccccccccc} 
& 2015 & 2016 & 2017 & 2018 & $\mathbf{2 0 1 9}$ & $\mathbf{2 0 2 0}$ & $\mathbf{2 0 2 1}$ & $\mathbf{2 0 2 2}$ & $\mathbf{2 0 2 3}$ \\
\hline ACTUAL & 3 & 4 & 4 & 4 & 4 &. &. &. &. \\
APPROVED GOALS &. &. & 5 & 5 & 5 & 5 & 5 & 5 &. \\
PROPOSED GOALS &. &. &. &. &. & 5 & 5 & 5 & 5
\end{tabular}

Freshmen in Top 10\% of High School Class

Fall 2014 Fall 2015 Fall 2016 Fall $2017 \quad$ Fall 2018 Fall $2019 \quad$ Fall 2020 Fall 2021 Fall 2022

\begin{tabular}{cccccccccc}
\hline ACTUAL & 28 & 30 & 33 & 34 & 32 &. &. &. &. \\
APPROVED GOALS & $\cdot$ &. & 30 & 33 & 34 & 35 & 35 & 36 &. \\
PROPOSED GOALS &. &. &. &. &. & 34.5 & 35.0 & 36.0 & 37.0
\end{tabular}

Time to Degree for FTICs in 120 hr programs

\begin{tabular}{|c|c|c|c|c|c|c|c|c|c|}
\hline & 2013-14 & 2014-15 & $2015-16$ & 2016-17 & 2017-18 & 2018-19 & 2019-20 & $2020-21$ & 2021-22 \\
\hline ACTUAL & 4.7 & 4.5 & 4.3 & 4.2 & 4.0 & . & . & . & . \\
\hline APPROVED GOALS & . & . & 4.5 & 4.3 & 4.2 & 4.2 & 4.2 & 4.2 & . \\
\hline PROPOSED GOALS & . & . & . & . & . & 4.0 & 4.0 & 4.0 & 4.0 \\
\hline \multicolumn{10}{|c|}{ Six-Year FTIC Graduation Rates [full-\& part-time students] } \\
\hline & $2008-14$ & $2009-15$ & $2010-16$ & 2011-17 & $2012-18$ & 2013-19 & 2014-20 & $2015-21$ & 2016-22 \\
\hline ACTUAL & 66.0 & 67.7 & 66.4 & 68.8 & 71.2 & . & . & . & . \\
\hline APPROVED GOALS & . & . & 66.7 & 70.0 & 69.0 & 71.0 & 74.0 & 75.0 & . \\
\hline PROPOSED GOALS & . & . & . & . & . & 71.3 & 72.1 & 72.1 & 73.3 \\
\hline
\end{tabular}

Bachelor's Degrees Awarded [First Majors Only]

\begin{tabular}{cccccccccc} 
& $2013-14$ & $2014-15$ & $2015-16$ & $2016-17$ & $2017-18$ & $2018-19$ & $2019-20$ & $2020-21$ & $2021-22$ \\
\hline ACTUAL & 9,390 & 9,290 & 9,222 & 9,504 & 9,680 &. &. &. & \\
APPROVED GOALS &. &. & 9,081 & 9,255 & 9,513 & 9,595 & 9,632 & 9,723 & $\cdot$ \\
PROPOSED GOALS &. &. &. &. &. & 9,765 & 9,842 & 9,923 & 10,044
\end{tabular}




\section{KEY PERFORMANCE INDICATORS (CONTINUED)}

\section{Teaching \& Learning Metrics}

\section{Professional Licensure \& Certification Exam First-time Pass Rates}

\begin{tabular}{lccccccccc}
\multicolumn{1}{c}{ CALENDAR YEAR } & $\mathbf{2 0 1 4}$ & $\mathbf{2 0 1 5}$ & $\mathbf{2 0 1 6}$ & $\mathbf{2 0 1 7}$ & $\mathbf{2 0 1 8}$ & $\mathbf{2 0 1 9}$ & $\mathbf{2 0 2 0}$ & $\mathbf{2 0 2 1}$ & $\mathbf{2 0 2 2}$ \\
Nursing & 86 & 90 & 94 & 93 & 94 & 93 & 100 & 100 & 100 \\
US Average & 85 & 87 & 85 & 87 & 92 &. &. &. &. \\
\hline Medicine $(2 \mathrm{Yr})$ & 95 & 96 & 94 & 92 & 98 & 98 & 100 & 100 & 100 \\
US Average & 96 & 95 & 96 & 96 & 96 &. &. &. &. \\
\hline Pharmacy &. & 94 & 91 & 86 & 83 & 90 & 100 & 100 & 100 \\
US Average & 95 & 93 & 86 & 88 & 89 & & & &
\end{tabular}

\begin{tabular}{lccccccccc}
\multicolumn{1}{c}{ CROSS-YEAR } & $\mathbf{2 0 1 3 - 1 4}$ & $\mathbf{2 0 1 4 - 1 5}$ & $\mathbf{2 0 1 5 - 1 6}$ & $\mathbf{2 0 1 6 - 1 7}$ & $\mathbf{2 0 1 7 - 1 8}$ & $\begin{array}{c}\text { 2018-19 } \\
\text { GOAL }\end{array}$ & $\begin{array}{c}\text { 2019-20 } \\
\text { GOAL }\end{array}$ & $\begin{array}{c}\text { 2020-21 } \\
\text { GOAL }\end{array}$ & $\begin{array}{c}\text { 2021-22 } \\
\text { GOAL }\end{array}$ \\
\hline Medicine (4Y-CK) & 98 & 97 & 99 & 95 & 98 & 98 & 100 & 100 & 100 \\
US Average & 97 & 95 & 96 & 96 & 97 &. &. &. &. \\
\hline Medicine (4Y-CS) & 91 & 96 & 97 & 96 & 97 & 98 & 100 & 100 & 100 \\
US Average & 96 & 96 & 97 & 96 & 95 &. &. &. &. \\
& & & & & & $\mathbf{2 0 1 7 - 1 9}$ & $\mathbf{2 0 1 8 - 2 0}$ & $\mathbf{2 0 1 9 - 2 1}$ & $\mathbf{2 0 2 0 - 2 2}$ \\
\multicolumn{1}{c}{ MULTI-YEAR } & $\mathbf{2 0 1 2 - 1 4}$ & $\mathbf{2 0 1 3 - 1 5}$ & $\mathbf{2 0 1 4 - 1 6}$ & $\mathbf{2 0 1 5 - 1 7}$ & $\mathbf{2 0 1 6 - 1 8}$ & GOAL & GOAL & GOAL & GOAL \\
\hline Physical Therapy & 97 & 95 & 94 & 95 & 94 & 93 & 100 & 100 & 100 \\
US Average & 90 & 91 & 92 & 92 & 92 &. &. &. &.
\end{tabular}

\section{Exam Scores Relative to Benchmarks}

\begin{tabular}{llllllllll}
\hline Above or Tied & 3 & 6 & 5 & 3 & 5 & 6 & 6 & 6 & 6 \\
Total & 5 & 6 & 6 & 6 & 6 & 6 & 6 & 6 & 6
\end{tabular}

Note: An asterisk $\left(^{*}\right)$ indicates the passing rate is preliminary. 


\section{KEY PERFORMANCE INDICATORS (CONTINUED)}

\section{Teaching \& Learning Metrics}

Graduate Degrees Awarded [First Majors Only]

\begin{tabular}{cccccccccc} 
& $2013-14$ & $2014-15$ & $2015-16$ & $2016-17$ & $2017-18$ & $2018-19$ & $2019-20$ & $2020-21$ & $2021-22$ \\
\hline ACTUAL & 3,401 & 3,773 & 3,918 & 4,208 & 4,170 &. &. &. & \\
APPROVED GOALS &. &. & 3,877 & 3,973 & 4,233 & 4,246 & 4,259 & 4,279 &. \\
PROPOSED GOALS &. &. &. &. &. & 4,161 & 4,177 & 4,195 & 4,215
\end{tabular}

Percent of Bachelor's Degrees Awarded to African-American \& Hispanic Students

\begin{tabular}{cccccccccc} 
& $2013-14$ & $2014-15$ & $2015-16$ & $2016-17$ & $2017-18$ & $2018-19$ & $2019-20$ & $2020-21$ & $2021-22$ \\
\hline ACTUAL & 29 & 30 & 31 & 32 & 30 &. &. &. &. \\
APPROVED GOALS &. &. & 30 & 31 & 32 & 32 & 32 & 32 &. \\
PROPOSED GOALS &. &. &. &. &. & 32.4 & 32.5 & 33.2 & 33.8
\end{tabular}

Percent of Adult (Aged 25+) Undergraduates Enrolled Fall 2014 Fall 2015 Fall 2016 Fall 2017 Fall 2018

Fall $2019 \quad$ Fall $2020 \quad$ Fall $2021 \quad$ Fall 2022

\begin{tabular}{cccccccccc}
\hline ACTUAL & 24 & 23 & 22 & 22 & 20 &. &. &. &. \\
APPROVED GOALS &. &. & 23 & 22 & 20 & 21 & 21 & 21 &. \\
PROPOSED GOALS &. &. &. &. &. & 20.5 & 20.8 & 20.8 & 20.9
\end{tabular}

Percent of Undergraduate FTE in Online Courses

\begin{tabular}{cccccccccc} 
& $2013-14$ & $2014-15$ & $2015-16$ & $2016-17$ & $2017-18$ & $2018-19$ & $2019-20$ & $2020-21$ & $2021-22$ \\
\hline ACTUAL & 23 & 26 & 28 & 29 & 32 &. &. &. &. \\
APPROVED GOALS &. &. & 28 & 28 & 30 & 31 & 32 & 33 &. \\
PROPOSED GOALS &. &. &. &. &. & 32.6 & 33.7 & 33.7 & 35.4
\end{tabular}

Percent of Bachelor's Degrees in STEM \& Health

\begin{tabular}{cccccccccc} 
& $2013-14$ & $2014-15$ & $2015-16$ & $2016-17$ & $2017-18$ & $2018-19$ & $2019-20$ & $2020-21$ & $2021-22$ \\
\hline ACTUAL & 34 & 38 & 42 & 44 & 45 &. &. &. &. \\
APPROVED GOALS &. &. & 41 & 42 & 44 & 45 & 45 & 45 &. \\
PROPOSED GOALS &. &. &. &. &. & 46.0 & 48.7 & 49.8 & 50.0
\end{tabular}

\section{Percent of Graduate Degrees in STEM \& Health}

\begin{tabular}{cccccccccc} 
& $2013-14$ & $2014-15$ & $2015-16$ & $2016-17$ & $2017-18$ & $\mathbf{2 0 1 8 - 1 9}$ & $\mathbf{2 0 1 9 - 2 0}$ & $\mathbf{2 0 2 0 - 2 1}$ & $\mathbf{2 0 2 1 - 2 2}$ \\
\hline ACTUAL & 52 & 57 & 60 & 63 & 60 &. &. &. &. \\
APPROVED GOALS &. &. & 60 & 61 & 63 & 63 & 64 & 64 &. \\
PROPOSED GOALS &. &. &. &. &. & 61 & 62 & 63 & 63
\end{tabular}




\section{KEY PERFORMANCE INDICATORS (CONTINUED)}

Scholarship, Research and Innovation Metrics

National Academy Memberships

\begin{tabular}{cccccccccc} 
& 2015 & 2016 & 2017 & 2018 & 2019 & $\mathbf{2 0 2 0}$ & $\mathbf{2 0 2 1}$ & $\mathbf{2 0 2 2}$ & $\mathbf{2 0 2 3}$ \\
\hline ACTUAL & 7 & 8 & 11 & 13 & 14 &. &. &. &. \\
APPROVED GOALS &. &. & 9 & 10 & 13 & 13 & 13 & 13 &. \\
PROPOSED GOALS &. &. &. &. &. & 14 & 15 & 16 & 17
\end{tabular}

Faculty Awards

Fall 2012 Fall 2013 Fall 2014 Fall 2015 Fall 2016 Fall 2017 Fall 2018 Fall 2019 Fall 2020

\begin{tabular}{|c|c|c|c|c|c|c|c|c|c|}
\hline ACTUAL & 5 & 8 & 8 & 13 & 13 & . & . & . & . \\
\hline APPROVED GOALS & . & . & 7 & 8 & 9 & 10 & 11 & 11 & . \\
\hline PROPOSED GOALS & . & . & . & . & . & 12 & 12 & 12 & 13 \\
\hline \multicolumn{10}{|c|}{ Total Research Expenditures (\$M) } \\
\hline & 2013-14 & 2014-15 & 2015-16 & 2016-17 & 2017-18 & 2018-19 & 2019-20 & 2020-21 & 2021-22 \\
\hline ACTUAL & 497 & 494 & 515 & 568 & 592 & . & . & . & . \\
\hline APPROVED GOALS & . & . & 495 & 510 & 569 & 570 & 571 & 572 & . \\
\hline PROPOSED GOALS & . & . & . & . & . & 600 & 601 & 602 & 603 \\
\hline
\end{tabular}

Percentage of Research Expenditures Funded from External Sources

\begin{tabular}{|c|c|c|c|c|c|c|c|c|c|}
\hline & 2013-14 & 2014-15 & 2015-16 & 2016-17 & 2017-18 & 2018-19 & $2019-20$ & 2020-21 & 2021-22 \\
\hline ACTUAL & 60 & 55 & 55 & 57 & 57 & . & . & . & . \\
\hline APPROVED GOALS & . & . & 56 & 57 & 58 & 59 & 60 & 60 & . \\
\hline PROPOSED GOALS & . & . & . & . & . & 59 & 60 & 60 & 60 \\
\hline \multicolumn{10}{|c|}{ Utility Patents Awarded [from the USPTO] } \\
\hline & 2014 & 2015 & 2016 & 2017 & 2018 & 2019 & 2020 & 2021 & 2022 \\
\hline ACTUAL & 110 & 90 & 114 & 120 & 101 & . & . & . & . \\
\hline APPROVED GOALS & . & . & . & 69 & 121 & 122 & 122 & 122 & . \\
\hline PROPOSED GOALS & . & . & . & . & . & 102 & 103 & 104 & 105 \\
\hline
\end{tabular}

Number of Licenses/Options Executed Annually

\begin{tabular}{cccccccccc} 
& $\mathbf{2 0 1 3 - 1 4}$ & $\mathbf{2 0 1 4 - 1 5}$ & $\mathbf{2 0 1 5 - 1 6}$ & $\mathbf{2 0 1 6 - 1 7}$ & $\mathbf{2 0 1 7 - 1 8}$ & $\mathbf{2 0 1 8 - 1 9}$ & $\mathbf{2 0 1 9 - 2 0}$ & $\mathbf{2 0 2 0 - 2 1}$ & $\mathbf{2 0 2 1 - 2 2}$ \\
\hline ACTUAL & 91 & 119 & 133 & 122 & 127 &. &. &. & \\
APPROVED GOALS &. & 119 & 120 & 121 & 123 & 123 & 123 & 123 &. \\
PROPOSED GOALS &. &. &. &. &. & 90 & 91 & 92 & 93
\end{tabular}




\section{KEY PERFORMANCE INDICATORS (CONTINUED)}

Scholarship, Research and Innovation Metrics

Number of Start-up Companies Created

\begin{tabular}{ccccccccccc} 
& $2012-13$ & $2013-14$ & $2014-15$ & $2015-16$ & $2016-17$ & $2017-18$ & $2018-19$ & $2019-20$ & $2020-21$ & $2021-22$ \\
\hline ACTUAL & 9 & 11 & 11 & 9 & 10 & 10 &. &. &. &. \\
APPROVED GOALS &. &. & 8 & 8 & 9 & 10 & 11 & 11 & 11 & 11 \\
PROPOSED GOALS &. &. &. &. &. &. & 10 & 11 & 11 & 12
\end{tabular}

Institution Specific Goals

To further distinguish the university's distinctive mission, the university may choose to provide additional metric goals that are based on the university's own strategic plan.

\section{SEE INDIVIDUAL USF SYSTEM CAMPUS ACCOUNTABILITY PLANS}




\section{ENROLLMENT PLANNING}

Fall Headcount Enrollment by Student Level (for all degree-seeking students at all campuses)

\begin{tabular}{|c|c|c|c|c|c|c|c|c|c|}
\hline & 2014 & 2015 & 2016 & 2017 & 2018 & 2019 & 2020 & 2021 & 2022 \\
\hline \multicolumn{10}{|l|}{ UNDERGRADUATE } \\
\hline ACTUAL & 35,808 & 35,990 & 36,373 & 36,955 & 37,235 & & & & \\
\hline APPROVED GOALS & . & 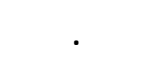 & . & 36,992 & 36,850 & 37,044 & 37,395 & 37,826 & . \\
\hline PROPOSED GOALS & & . & . & 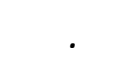 & . & 37,323 & 38,283 & 39,215 & 40,358 \\
\hline \multicolumn{10}{|l|}{ GRADUATE } \\
\hline ACTUAL & 10,555 & 10,698 & 10,983 & 11,569 & 11,438 & & & & \\
\hline APPROVED GOALS & . & & . & 11,094 & 11,657 & 11,765 & 11,891 & 12,023 & . \\
\hline PROPOSED GOALS & & . & . & 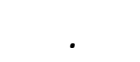 & . & 11,497 & 11,571 & 11,646 & 11,749 \\
\hline
\end{tabular}

Fall Headcount Enrollment by Student Type (for all degree-seeking students at all campuses)

\begin{tabular}{|c|c|c|c|c|c|c|c|c|c|}
\hline & $\begin{array}{c}2014 \\
\text { ACTUAL }\end{array}$ & $\begin{array}{c}2015 \\
\text { ACTUAL }\end{array}$ & $\begin{array}{c}2016 \\
\text { ACTUAL }\end{array}$ & $\begin{array}{c}2017 \\
\text { ACTUAL }\end{array}$ & $\begin{array}{c}2018 \\
\text { ACTUAL }\end{array}$ & $\begin{array}{l}2019 \\
\text { PLAN }\end{array}$ & $\begin{array}{l}2020 \\
\text { PLAN }\end{array}$ & $\begin{array}{l}2021 \\
\text { PLAN }\end{array}$ & $\begin{array}{l}2022 \\
\text { PLAN }\end{array}$ \\
\hline \multicolumn{10}{|l|}{ UNDERGRADUATE } \\
\hline FTIC & 17,378 & 17,704 & 18,023 & 18,189 & 18,575 & 19,006 & 19,694 & 20,341 & 21,171 \\
\hline FCS AA Transfers & 9,172 & 9,108 & 9,245 & 9,416 & 9,501 & 9,275 & 9,625 & 10,039 & 10,386 \\
\hline Other AA Transfers & 1,565 & 1,495 & 1,429 & 1,511 & 1,449 & 1,433 & 1,453 & 1,476 & 1,495 \\
\hline Post-Baccalaureates & 1,110 & 1,025 & 998 & 986 & 901 & 985 & 997 & 1,005 & 1,012 \\
\hline Other Undergraduates & 6,583 & 6,658 & 6,678 & 6,853 & 6,809 & 6,624 & 6,514 & 6,354 & 6,294 \\
\hline Subtotal & 35,808 & 35,990 & 36,373 & 36,955 & 37,235 & 37,323 & 38,283 & 39,215 & 40,358 \\
\hline \multicolumn{10}{|l|}{ GRADUATE } \\
\hline Master's & 6,950 & 7,160 & 7,302 & 7,690 & 7,489 & 7,530 & 7,580 & 7,631 & 7,684 \\
\hline Research Doctoral & 2,226 & 2,229 & 2,333 & 2,443 & 2,461 & 2,475 & 2,495 & 2,515 & 2,535 \\
\hline Professional Doctoral & 1,379 & 1,309 & 1,348 & 1,436 & 1,488 & 1,492 & 1,496 & 1,500 & 1,530 \\
\hline Subtotal & 10,555 & 10,698 & 10,983 & 11,569 & 11,438 & 11,497 & 11,571 & 11,646 & 11,749 \\
\hline TOTAL & 46,363 & 46,688 & 47,356 & 48,524 & 48,673 & 48,820 & 49,854 & 50,861 & 52,107 \\
\hline
\end{tabular}

Notes: This table reports the number of students enrolled at the university by student type categories. The student type for undergraduates is based on the Type of Student at Time of Most Recent Admission. The student type for graduates is based on the degree that is sought and the student CIP code. Does not include 'Unclassified' students who are not formally admitted into a degree program but are enrolled (e.g., dual enrolled high school students).

\section{Percent of Baccalaureate-Seeking Resident Undergraduates Who Earned 15+ Credit Hours} (Fall terms only)

\begin{tabular}{cccccc|cccc} 
& 2014 & 2015 & 2016 & 2017 & 2018 & 2019 & 2020 & 2021 & 2022 \\
\hline ACTUAL & 24 & 23 & 21 & 21 & 20 &. &. &. &. \\
APPROVED GOALS & $\cdot$ & $\cdot$ & $\cdot$ & $\cdot$ & $\cdot$ &. &. &. &. \\
PROPOSED GOALS &. &. &. &. &. & 20 & 21 & 22 & 24
\end{tabular}




\section{ENROLLMENT PLANNING continued}

\begin{tabular}{|c|c|c|c|c|c|c|c|c|c|c|}
\hline & $\begin{array}{l}2013-14 \\
\text { ACTUAL }\end{array}$ & $\begin{array}{l}2014-15 \\
\text { ACTUAL }\end{array}$ & $\begin{array}{l}\text { 2015-16 } \\
\text { ACTUAL }\end{array}$ & $\begin{array}{l}2016-17 \\
\text { ACTUAL }\end{array}$ & $\begin{array}{l}2017-18 \\
\text { ACTUAL }\end{array}$ & $\begin{array}{l}2018-19 \\
\text { PLAN }\end{array}$ & $\begin{array}{c}2019-20 \\
\text { PLAN }\end{array}$ & $\begin{array}{l}2020-21 \\
\text { PLAN }\end{array}$ & $\begin{array}{l}2021-22 \\
\text { PLAN }\end{array}$ & $\begin{array}{l}2022-23 \\
\text { PLAN }\end{array}$ \\
\hline \multicolumn{11}{|l|}{ RESIDENT } \\
\hline LOWER & 12,087 & 11,844 & 11,933 & 12,066 & 12,092 & 12,044 & 12,334 & 12,514 & 12,719 & 12,930 \\
\hline UPPER & 19,341 & 18,957 & 18,827 & 18,338 & 18,823 & 18,904 & 18,605 & 18,458 & 19,653 & 19,866 \\
\hline GRAD I & 4,794 & 4,744 & 4,568 & 4,339 & 4,401 & 4,389 & 4,401 & 4,416 & 4,433 & 4,448 \\
\hline GRAD ॥ & 1,266 & 1,279 & 1,199 & 1,219 & 1,267 & 1,285 & 1,290 & 1,295 & 1,302 & 1,309 \\
\hline TOTAL & 37,487 & 36,825 & 36,528 & 35,962 & 36,583 & 36,621 & 36,630 & 36,683 & 38,107 & 38,553 \\
\hline \multicolumn{11}{|c|}{ NON-RESIDENT } \\
\hline LOWER & 1,357 & 1,574 & 1,862 & 1,992 & 1,949 & 1,930 & 2,061 & 2,202 & 2,307 & 2,389 \\
\hline UPPER & 1,058 & 1,304 & 1,596 & 1,819 & 1,974 & 2,104 & 2,244 & 2,362 & 2,501 & 2,647 \\
\hline GRAD I & 1,370 & 1,652 & 1,984 & 2,142 & 2,133 & 2,034 & 2,046 & 2,058 & 2,078 & 2,102 \\
\hline GRAD ॥ & 853 & 880 & 935 & 1,017 & 1,118 & 1,156 & 1,142 & 1,150 & 1,170 & 1,201 \\
\hline TOTAL & 4,638 & 5,411 & 6,377 & 6,970 & 7,173 & 7,224 & 7,492 & 7,771 & 8,056 & 8,339 \\
\hline \multicolumn{11}{|l|}{ TOTAL } \\
\hline LOWER & 13,443 & 13,419 & 13,795 & 14,057 & 14,041 & 13,974 & 14,395 & 14,716 & 15,026 & 15,319 \\
\hline UPPER & 20,400 & 20,262 & 20,423 & 20,158 & 20,796 & 21,007 & 20,849 & 20,820 & 22,153 & 22,513 \\
\hline GRAD I & 6,164 & 6,396 & 6,553 & 6,482 & 6,534 & 6,423 & 6,447 & 6,474 & 6,512 & 6,549 \\
\hline GRAD ॥ & 2,118 & 2,159 & 2,134 & 2,236 & 2,385 & 2,441 & 2,432 & 2,445 & 2,472 & 2,510 \\
\hline TOTAL & 42,125 & 42,236 & 42,905 & 42,932 & 43,756 & 43,845 & 44,122 & 44,455 & 46,163 & 46,892 \\
\hline
\end{tabular}

Note: Full-time Equivalent (FTE) student is a measure of all instructional activity (regardless of fundability) that is based on the number of credit hours for all students. FTE is based on the standard national definition, which divides undergraduate credit hours by 30 and graduate credit hours by 24 . Pursuant to section 1013.31, Florida Statutes, Board facilities staff use this data as a key factor in the calculation of facility space needs for university educational plant surveys.

\begin{tabular}{|c|c|c|c|c|c|c|c|c|c|c|}
\hline \multicolumn{11}{|c|}{ Percent of FTE Enrollment by Method of Instruction } \\
\hline & 2013-14 & 2014-15 & 2015-16 & 2016-17 & $2017-18$ & 2018-19 & $2019-20$ & $2020-21$ & 2021-22 & $2022-23$ \\
\hline & ACTUAL & ACTUAL & ACTUAL & ACTUAL & ACTUAL & PLAN & PLAN & PLAN & PLAN & PLAN \\
\hline \multicolumn{11}{|l|}{ UNDERGRADUATE } \\
\hline Distance (80-100\%) & $23 \%$ & $26 \%$ & $28 \%$ & $29 \%$ & $32 \%$ & $33 \%$ & $33 \%$ & $34 \%$ & $35 \%$ & $36 \%$ \\
\hline Hybrid (50-79\%) & $2 \%$ & $2 \%$ & $1 \%$ & $1 \%$ & $1 \%$ & $0 \%$ & $0 \%$ & $0 \%$ & $0 \%$ & $0 \%$ \\
\hline Classroom (0-50\%) & $75 \%$ & $72 \%$ & $72 \%$ & $70 \%$ & $67 \%$ & $67 \%$ & $66 \%$ & $66 \%$ & $65 \%$ & $64 \%$ \\
\hline \multicolumn{11}{|l|}{ GRADUATE } \\
\hline Distance (80-100\%) & $22 \%$ & $24 \%$ & $24 \%$ & $27 \%$ & $30 \%$ & $31 \%$ & $32 \%$ & $32 \%$ & $33 \%$ & $34 \%$ \\
\hline Hybrid (50-79\%) & $3 \%$ & $2 \%$ & $1 \%$ & $1 \%$ & $2 \%$ & $2 \%$ & $2 \%$ & $2 \%$ & $2 \%$ & $2 \%$ \\
\hline Classroom (0-50\%) & $75 \%$ & $74 \%$ & $75 \%$ & $72 \%$ & $68 \%$ & $67 \%$ & $66 \%$ & $65 \%$ & $65 \%$ & $64 \%$ \\
\hline
\end{tabular}

Note: Full-time Equivalent (FTE) student is a measure of instructional activity (regardless of fundability) that is based on the number of credit hours that degreeseeking students enroll. FTE is based on the standard national definition, which divides undergraduate credit hours by 30 and graduate credit hours by 24 . Distance Learning is a course in which at least 80 percent of the direct instruction of the course is delivered using some form of technology when the student and instructor are separated by time or space, or both (per 1009.24(17), F.S.). Classroom/Traditional, is a course in which less than 50\% of the direct instruction of the course is delivered using some form of technology when the student and instructor are separated by time, space or both. This designation can include activities that do not occur in a classroom (ie, labs, internships, practica, clinicals, labs, etc) - see SUDS data element \#2052. *Percentages may not total 100 due to rounding. 


\section{ACADEMIC PROGRAM COORDINATION}

\section{New Programs For Consideration by University in AY 2019-20}

The S.U.S. Council of Academic Vice Presidents (CAVP) Academic Program Coordination Work Group will review these programs as part of their on-going coordination efforts. The programs listed below are based on the 2018 Accountability Plan list for programs under consideration for 2019-21.

\begin{tabular}{|c|c|c|c|c|c|c|}
\hline PROGRAM TITLES & $\begin{array}{l}\text { CIP CODE } \\
\text { 6-digit }\end{array}$ & $\begin{array}{c}\text { AREA OF } \\
\text { STRATEGIC } \\
\text { EMPHASIS }\end{array}$ & $\begin{array}{c}\text { OTHER } \\
\text { UNIVERSITIES } \\
\text { WITH SAME } \\
\text { PROGRAM }\end{array}$ & $\begin{array}{l}\text { OFFERED VIA } \\
\text { DISTANCE } \\
\text { LEARNING } \\
\text { IN SYSTEM }\end{array}$ & $\begin{array}{c}\text { PROJECTED } \\
\text { ENROLLMENT } \\
\text { in 5th year }\end{array}$ & $\begin{array}{c}\text { PROPOSED DATE } \\
\text { OF SUBMISSION } \\
\text { TO UBOT }\end{array}$ \\
\hline \multicolumn{7}{|l|}{ BACHELOR'S PROGRAMS } \\
\hline Management Science & 52.1301 & STEM & FIU, FPU, UF & $100 \%$ & 25 & Spring 2020 \\
\hline Information Science & 11.0104 & STEM & None & $95 \%$ & 350 & Spring 2020 \\
\hline Cell and Molecular Biology & 26.0406 & STEM & None & $0 \%$ & 800 & Spring 2020 \\
\hline Marine Biology & 26.1302 & STEM & FIU, UWF & $0 \%$ & 400 & Spring 2020 \\
\hline \multicolumn{7}{|c|}{ MASTER'S, SPECIALIST AND OTHER ADVANCED MASTER'S PROGRAMS } \\
\hline $\begin{array}{l}\text { Marriage and Family } \\
\text { Therapy/Counseling }\end{array}$ & 51.1505 & HEALTH & UCF, UF & $20 \%$ & 40 & Fall 2019 \\
\hline DOCTORAL PROGRAMS & & & & & & \\
\hline
\end{tabular}

$\mathrm{N} / \mathrm{A}$

\section{New Programs For Consideration by University in 2020-22}

These programs will be used in the 2020 Accountability Plan list for programs under consideration for 2020-21.

\begin{tabular}{|c|c|c|c|c|c|c|}
\hline \multirow[b]{5}{*}{ PROGRAM TITIES } & \multirow{5}{*}{$\begin{array}{l}\text { CIP CODE } \\
\text { 6-digit }\end{array}$} & \multicolumn{5}{|c|}{ OFFERED } \\
\hline & & & OTHER & VIA & & PROPOSED \\
\hline & & AREA OF & UNIVERSITIES & DISTANCE & PROJECTED & DATE OF \\
\hline & & STRATEGIC & WITH SAME & LEARNING & ENROLLMENT & SUBMISSION \\
\hline & & EMPHASIS & PROGRAM & IN SYSTEM & in 5 th year & ТО UВOT \\
\hline \multicolumn{7}{|l|}{ BACHELOR'S PROGRAMS } \\
\hline International/Global Studies & 30.2001 & GLOBAL & $\begin{array}{l}\text { NCF, UCF, } \\
\text { UF, UNF }\end{array}$ & $20 \%$ & 65 & Spring 2021 \\
\hline Design & 50.0499 & None & None & $20 \%$ & 70 & Spring 2021 \\
\hline \multicolumn{7}{|c|}{ MASTER'S, SPECIALIST AND OTHER ADVANCED MASTER'S PROGRAMS } \\
\hline & & & FAU, FGCU & & & \\
\hline $\begin{array}{l}\text { Appiled Ivatnematics, } \\
\text { General }\end{array}$ & 27.0301 & STEM & $\begin{array}{l}\text { FIU, UCF, } \\
\text { UNF }\end{array}$ & $0 \%$ & 35 & Spring 2021 \\
\hline Financial Planning \& Services & 52.0804 & None & None & $20 \%$ & 40 & Spring 2021 \\
\hline Management Science & 52.1301 & STEM & FSU & $20 \%$ & 50 & Spring 2021 \\
\hline \multicolumn{7}{|l|}{ DOCTORAL PROGRAMS } \\
\hline Ph.D. Pharmacy & 51.2099 & HEALTH & FAMU & $0 \%$ & 20 & TBD \\
\hline $\begin{array}{l}\text { OTD Occupational } \\
\text { Therapy/Therapist }\end{array}$ & 51.2306 & HEALTH & UF & $0 \%$ & 80 & TBD \\
\hline
\end{tabular}

